\title{
Pengaruh Penambahan Abu Arang Tempurung Kelapa Pada Tanah Lempung Terhadap Hasil Uji Kompaksi
}

\author{
Brigita Suzanna*1, Irwan Lie Keng Wong ${ }^{* 2}$, Monika Datu Mirring Palinggi³ \\ ${ }^{* 1}$ Mahasiswa Program Studi Teknik Sipil, Universitas Kristen Indonesia Paulus, Makassar \\ Email brigitasuzanna98@gmail.com \\ *2 Dosen Program Studi Teknik Sipil, Universitas Kristen Indonesia Paulus, Makassar \\ Email irwanliekengwong@gmail.com \\ *3 Dosen Program Studi Teknik Sipil, Universitas Kristen Indonesia Paulus, Makassar \\ Email monikadatumirring@gmail.com
}

\begin{abstract}
ABSTRAK
Tujuan dilakukannya penelitian ini adalah untuk mengetahui sifat fisis tanah lempung dan menganalis pengaruh penambahan abu arang tempurung kelapa pada tanah lempung. Adapun sampel tanah yang digunakan pada penelitian ini berasal dari Kecamatan Tanralili Kabupaten Maros, diambil dua titik sampel dan variasi kadar penambahan abu arang tempurung kelapa yaitu $0 \%, 4 \%, 6 \%, 8 \%, 10 \%$. Metode pengujian yang digunakan mengacu pada ASTM (American Society for Testing Material). Pengujian yang dilakukan yaitu pengujian sifat fisis tanah berupa kadar air, berat jenis, batas-batas Atterberg, analisa saringan, dan analisa hidrometer, kemudian dilakukan pengujian kompaksi (Compaction Test) untuk mengetahui kepadatan tanah maksimum. Hasil dari pengujian didapatkan nilai kadar air $28,811 \%$, berat jenis $2,58 \mathrm{gr} / \mathrm{cm}^{3}$ sehingga digolongkan dalam tanah lempung organik. Serta nilai indeks plastisitas $9,926 \%$ dengan sifat plastisitas tergolong sedang dari interval 7\%-17\%. Kemudian dari hasil pengujian pemadatan tanah dengan penambahan abu tempurung kelapa didapatkan nilai kepadatan kering $(\gamma d r y)$ sebesar $0.862,0.886,0.914,0.943,0.962$ hal ini berarti sampel tanah mengalami peningkatan kepadatan kering ( $\gamma d r y)$ sebesar 11,60\%. Dari hasil penelitian dapat disimpulkan bahwa dengan penambahan abu arang tempurung kelapa dapat meningkatkan nilai kepadatan kering tanah sehingga dapat digunakan untuk meningkatkan nilai daya dukung tanah lempung.
\end{abstract}

\section{Kata Kunci : Karakteristik Tanah, Compaction Standar Proctor}

\section{ABSTRACT}

The purpose of this research is to determine the physical properties of clay soil and to analyze the effect of adding coconut shell charcoal ash to the clay soil. The soil samples used in this study came from Tanralili District, Maros Regency, two sample points were taken and the variations in the levels of addition of coconut shell charcoal ash is $0 \%$, $4 \%, 6 \%, 8 \%, 10 \%$. The test method used refers to ASTM (American Society for Testing Materials). The tests carried out were testing the physical properties of the soil in the form of moisture content, specific gravity, Atterberg boundaries, filter analysis, and hydrometer analysis, then a compaction test was carried out to determine the maximum soil density. The results of the test obtained a moisture content value of $28.811 \%$, a specific gravity of $2.58 \mathrm{~g} / \mathrm{cm} 3$ so that it is classified as organic clay. As well as the plasticity index value of $9.926 \%$ with moderate plasticity from the $7 \%-17 \%$ interval. Then from the test results of soil compaction testing with the addition of coconut shell ash, the dry density ( $\gamma$ dry) equal to $0.862,0.886,0.914,0.943,0.962$, this means that the soil sample experienced an increase in dry density ( $\gamma$ dry) of $11.60 \%$. From the research results it can be concluded that the addition of coconut shell charcoal ash can increase the value of soil dry density so that it can be used to increase the value of the carrying capacity of clay soil.

Key Words : Soil Characteristics, Compaction Standard Proctor

\section{PENDAHULUAN}

Tanah merupakan material yang tersusun dari agregat (butiran) mineral-mineral padat yang tidak tersementasi (terikat secara kimia) satu sama lain dan dari bahan-bahan organik yang telah melapuk (berpatikel padat) disertai dengan zat cair dan gas yang mengisi ruang-ruang kosong di antara partikel padat tersebut. [1]
Umumnya tanah dibedakan menjadi dua yaitu tanah kohesif dan tanah non kohesif atau sebagai tanah berbutir kasar dan halus. Jenis dan sifat tanah sangat bervariasi, yang ditentukan dari perbandingan banyaknya fraksi (kerikil, pasir, lanau, dan lempung) serta gradasi dan sifat plastisitas butir halus. [2] 
Ada dua sistem klasifikasi yang biasa dipakai dalam bidang teknik sipil yaitu sistem klasifikasi USCS yang didasarkan pada persentase fraksi, bentuk kurva gradasi, plastisitas kompresibilitas, dan AASHTO yang dikembangkan berdasarkan hasil pengamatan tanah di bawah perkerasan serta merupakan sistem yang dikenal secara luas dan sering digunakan oleh insinyur jalan raya. [3]

Tanah lempung memiliki sifat yang elastis sehingga mengakibatkan tanah dapat mengembang dan menyusut, saat musim hujan permukaan air tanah meningkat tinggi dan tanah mereka pada saat musim kemarau, sehingga jika ada bangunan struktur atau infrastruktur di atas tanah maka dapat menyebabkan kerusakan pada struktur atau infrastruktur tersebut seperti terjadi retak pada dindingnya atau terjadi penurunan, serta yang paling sering terjadi yaitu terjadinya keretakan pada plat lantai dan penurunan badan jalan pada konstruksi jalan.

Stabilisasi tanah adalah usaha untuk memperbaiki sifat-sifat tanah yang ada, sehingga didapatkan sifat-sifat tanah yang memenuhi syarat-syarat teknis untuk lokasi konstruksi bangunan. Tujuan utama stabilitas adalah untuk mengubah sifat-sifat fisis tanah itu sendiri, seperti sifat kompresibilitas, kapasitas daya dukung, kemudahan untuk dikerjakan, permeabilitas, sensitifitasnya terhadap kadar air yang berubah, serta potensi pengembangannya. [4]

Salah satu metode perbaikan tanah yaitu dengan menambahkan bahan additive. Dalam hal ini bahan

Tabel 1. Elemen pengujian pemadatan di laboratorium

\begin{tabular}{|c|c|c|}
\hline & $\begin{array}{r}\text { Proctor Standar } \\
698)\end{array}$ & $\begin{array}{r}\text { Proctor Modifikasi } \\
\text { 1557) }\end{array}$ \\
\hline Berat Palu & $24,5 \mathrm{~N}(5,5$ 1b/2,5 kg) & $44,5 \mathrm{~N}(10$ 1b/4,5 kg) \\
\hline Tinggi jatuh palu & $350 \mathrm{~mm}$ (12 inc) & $457 \mathrm{~mm}$ (18 inc) \\
\hline Jumlah lapisan & 3 & 5 \\
\hline Jumlah tumbukan / lapisan & 25 & 56 \\
\hline Volume cetakan & \multicolumn{2}{|c|}{$1 / 30 \mathrm{ft}^{3}$} \\
\hline Tanah & \multicolumn{2}{|c|}{ Saringan (-) No. 4} \\
\hline Energi pemadatan & $595 \mathrm{kj} / \mathrm{m}^{3}$ & $2698 \mathrm{kj} / \mathrm{m}^{3}$ \\
\hline
\end{tabular}

Penelitian sebelumnya atau terkait antara lain :Karaseran (2015) "Pengaruh Bahan Campuran Arang Tempurung Terhadap Konsolidasi Sekunder Pada Lempung Ekspansif". Dari hasil pengujian pemadatan proctor standard dengan penambahan arang tempurung dengan variasi $4 \%, 6 \%, 8 \%$, dan campuran yang digunakan adalah abu arang tempurung kelapa, karena abu arang tempurung kelapa memiliki kemampuan memperbaiki sirkulasi air dan udara, serta sebagai media pengikat. Selain itu,penggunaan campuran ini untuk mengoptimalkan pemanfaatan tempurung kelapa. [5]

Pemadatan merupakan peristiwa naiknya berat volume kering yang disebabkan oleh beban dinamis untuk menjadi kompak melalui pengurangan rongga udara. [6] Pengujian pemadatan yang dilakukan di laboratorium untuk memperoleh kadar air optimum dan berat isi kering maksimum. Komponen yang mempengaruhi pemadatan tanah adalah sifat dasar dari tanah yang tergantung pada jenis mineral dan komposisinya dalam tanah, kadar air tanah, serta energi pemadat yang diberikan. [7] Uji pemadatan ada dua jenis yakni proctor standar dan proctor modifikasi. [8]

Percobaan dilakukan beberapa kali dengan kadar air yang berbeda-beda. Setelah dipadatkan, benda uji ditimbang dan diukur kadar air dan berat berat volumenya. Hubungan grafis dari kadar air dan berat volumenya kemudian diplot untuk membentuk kurva pemadatan. Kepadatan kering maksimum diperoleh dari titik puncak kurva pemadatan dengan kadar air yang optimal. Rincian mengenai persamaan dan perbedaan dari proctor standar dan proctor modifikasi dapat dilihat pada tabel 1. berikut 
Paulus Civil Engineering Journal

Jurnal Teknik Sipil UKI-Paulus Makassar

https://doi.org/10.52722/pcej.v3i2.3220

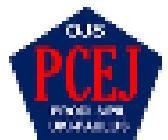

Volume 3 No.2, Juni 2021

e-ISSN 2775-4529

p-ISSN 2775-8613
Utara). Dari hasil pengujian pemadatan tanah menggunakan proctor standard dengan penambahan abu batubara pada variasi $0 \%, 10 \%$, $15 \%$, $20 \%$, dan $25 \%$ menunjukkan terjadinya peningkatan kepadatan kering dari variasi $0 \%$ sebesar 1,307 terus bertambah hingga 25\% sebesar 1,379. [10]

Tujuan dari penelitian ini adalah mengetahui sifat fisis tanah asli dari Jalan Damai Kecamatan Tanralili Kabupaten Maros Provinsi Sulawesi Selatan. Mengetahui klasifikasi tanah dari Jalan Damai Kabupaten Maros menurut metode USCS dan metode AASTHO. Menganalis bagaimana pengaruh penambahan abu arang tempurung kelapa pada tanah lempung terhadap hasil uji kompaksi (Compaction Test).

\section{METODE}

Sampel tanah penelitian diambil dari Jalan Damai Kecamatan Tanralili Kabupaten Maros, dapat dilihat pada gambar 1. Peneliti mengambil sampel sebanyak 2 titik dengan jarak antara titik 1 dan titik 2 sejauh 50 meter, pengukuran dilakukan dengan menggunakan alat ukur meteran rol. Banyaknya sampel tanah yang diambil dari masing masingmasing titik kurang lebih $75 \mathrm{~kg}$. Sedangkan limbah tempurung kelapa diperoleh dari beberapa pedagang kelapa di sekitar Pasar Daya, tempurung kelapa yang telah terkumpul dibersihkan dari serabut-serabutnya lalu dikeringkan dengan cara dijemur. Setelah kering, tempurung kelapa dibakar hingga menjadi arang, kemudian dihaluskan dengan cara ditumbuk dan disaring menggunakan saringan No. 40.

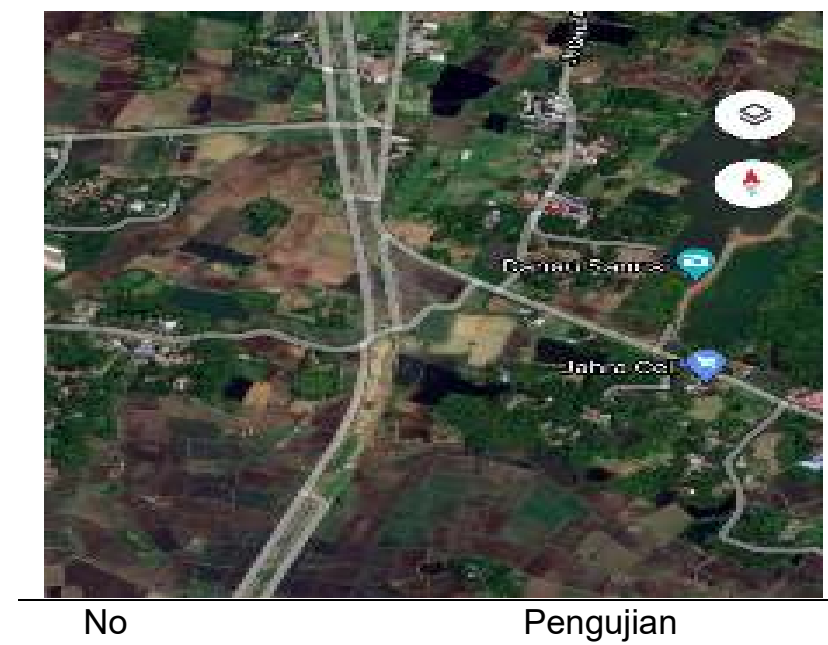

\section{Gambar 1. Lokasi Penelitian}

\section{Pe Titik 1 Kgrakteristik Tanah}

Pengujıan karakteristik tanah dilakukan sesuai dengan metode ASTM American Standard Testing and Material) antara lain:

a. Kadar Air (ASTM D-2216). Pengujian kadar air bertujuan untuk mengetahui jumlah air yang mengisi pori-port $t$

b. Berat Jenis (AS Titik 2 . Pengujian berat jenis bertujuan untuk mendapatkan berat jenis tanah sehingga dapat ditentukan jenis tanahnya berdasarkan nilai berat jenis.

c. Batas-batas Atterberg (ASTM D 4318-95). . Pengujian batas-batas Atterberg bertujuan untuk mendapatkan nilai batas cair (Liquid Limit), batas plastis (Plastic Limit), dan batas susut (Shrinkage Limit).

d. Analisa Butiran (ASTM D 422-72) dan (ASTM D 1140-54). Pengujian Analisa butiran bertujuan untuk menentukan pembagian butiran dari setiap tanah dan untuk mengetahui berapa besar ukuran butiran setiap tanah.

\section{Pengujian Kompaksi (Standard Proctor)}

Pengujian pemadatan tanah atau kompaksi dilakukan dengan menggunakan tanah asli dalam keadaan kering dan ditambahkan dengan abu arang tempurung kelapa sebanyak $0 \%, 4 \%, 6 \%$, $8 \%$, dan $10 \%$. Hasil pengujian ini untuk mengetahui pengaruh penambahan abu arang tempurung kelapa pada tanah lempung.

\section{Rancangan Benda Uji}

a. Sampel Benda Uji Jumlah benda uji untuk pengujian tiap titik bisa dilihat pada tabel 2 .

Tabel 2. Rancangan benda uji 


\begin{tabular}{llcc}
\hline & & Setiap Titik & \\
\hline 1 & Kadar air tanah asli & 3 & 6 \\
2 & Berat jenis & 2 & 4 \\
3 & Gradasi & 1 & 2 \\
4 & Batas-batas atterberg & & \\
& Batas Cair & 4 & 4 \\
& Batas Susut & 2 & 6 \\
& Batas Plastis & 3 & 50 \\
\hline & Kompaksi & 25 & \\
\hline
\end{tabular}

b. Rancangan variasi campuran pembuatan benda

uji kompaksi tiap titik

Tabel 3. Kebutuhan benda uji pemadatan

\begin{tabular}{cccccc}
\hline \multirow{2}{*}{ Bahan } & \multicolumn{5}{c}{ Persentase Campuran } \\
\cline { 2 - 6 } & $0 \%$ & $4 \%$ & $6 \%$ & $8 \%$ & $10 \%$ \\
\hline Abu Tempurung Kelapa (gr) & 0 & 120 & 180 & 240 & 300 \\
Tanah Asli (kg) & 3 & 3 & 3 & 3 & 3 \\
\hline
\end{tabular}

Kebutuhan bahan utama uji pemadatan :

Jumlah tanah untuk variasi $\quad=3 \mathrm{~kg} \times 5$ sampel

$=15 \mathrm{~kg}$

Jumlah tanah untuk 5 variasi $\quad=15 \mathrm{~kg} \times 5$ sampel

Total tanah $=75 \mathrm{~kg} \times 2$

$=75 \mathrm{~kg}$

$=150 \mathrm{~kg}$
1. Hasil Pengujian Karakteristik Tanah

Dari pengujian sifat fisis tanah yang telah dilakukan diperoleh hasil dari masing-masing pengujian dapat dilihat pada tabel 4 . sebagai berikut:

\section{HASIL DAN PEMBAHASAN}

Tabel 4. Rekapitulasi hasil pengujian sifat fisis tanah

\begin{tabular}{|c|c|c|c|c|c|c|}
\hline \multirow[t]{2}{*}{ No } & \multicolumn{3}{|c|}{ Pemeriksaan } & \multicolumn{3}{|c|}{ Nilai } \\
\hline & & & & Titik 1 & Titik 2 & Rata-rata \\
\hline 1 & \multicolumn{2}{|c|}{ Kadar Air $(\omega)$} & $\%$ & 27,994 & 29,627 & 28,811 \\
\hline 2 & \multicolumn{2}{|c|}{ Berat Jenis (Gs) } & $\mathrm{gr} / \mathrm{cm}^{3}$ & 2,58 & 2,59 & 2,58 \\
\hline \multirow[t]{4}{*}{3} & \multirow{4}{*}{ 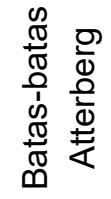 } & Batas Cair (LL) & $\%$ & 30,479 & 33,713 & 32,096 \\
\hline & & Batas Plastis (PL) & $\%$ & 21,167 & 23,175 & 22,171 \\
\hline & & Batas Susut (SL) & $\%$ & 18,016 & 11,839 & 14,928 \\
\hline & & Indeks Plastisitas (PI) & $\%$ & 9,312 & 10,539 & 9,926 \\
\hline \multirow[t]{6}{*}{4} & \multirow{6}{*}{$\begin{array}{l}\bar{n} \\
\frac{\pi}{0} \\
\mathbb{\pi} \\
\overline{0}\end{array}$} & Persen Lolos Saringan & $\%$ & 85,865 & 83,865 & 84,865 \\
\hline & & No.200 & & & & \\
\hline & & Gravel (G) & $\%$ & 0 & 0 & 0 \\
\hline & & Sand (S) & $\%$ & 14,135 & 16,562 & 15,349 \\
\hline & & Silt (M) & $\%$ & 71,279 & 71,583 & 71,431 \\
\hline & & Clay (C) & $\%$ & 14,586 & 11,855 & 13,221 \\
\hline
\end{tabular}

Hasil Analisis Pengujian Sifat Fisis Tanah :

\section{a. Pemeriksaan Kadar Air}

Pada pemeriksaan kadar air tanah asli diperoleh nilai kadar air pada titik 1 sebesar 27,994\%, titik 2 sebesar $29,627 \%$, dan nilai rata-rata sebesar $28,811 \%$.

b. Pemeriksaan Berat Jenis Tanah
Pada pemeriksaan berat jenis tanah diperoleh nilai berat jenis pada titik 1 sebesar 2,58 dan titik 2 sebesar 2,59 sehingga didapatkan nilai rata-rata sebesar 2,58. Dari hasil tersebut menunjukkan bahwa tanah yang telah dilakukan pemeriksaan termasuk dalam kelompok tanah lempung organik.

c. Pemeriksaan Batas-Batas Atterberg 
Paulus Civil Engineering Journal

Jurnal Teknik Sipil UKI-Paulus Makassar

https://doi.org/10.52722/pcej.v3i2.3220

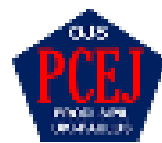

Volume 3 No.2, Juni 2021

e-ISSN 2775-4529

p-ISSN 2775-8613
Pada pemeriksaan batas-batas Atterberg yang telah dilakukan didapatkan batas cair, batas plastis dan batas susut pada tabel 5. dan gambar 2 . sebagai berikut :

Tabel 5. Pengujian batas-batas Atterberg

\begin{tabular}{cccc}
\hline & LL & PL & IP \\
\hline Titik 1 & 30,479 & 21,167 & 9,312 \\
Titik 2 & 33,713 & 23,175 & 10,539 \\
Rata-rata & 32,096 & 22,171 & 9,926 \\
\hline
\end{tabular}

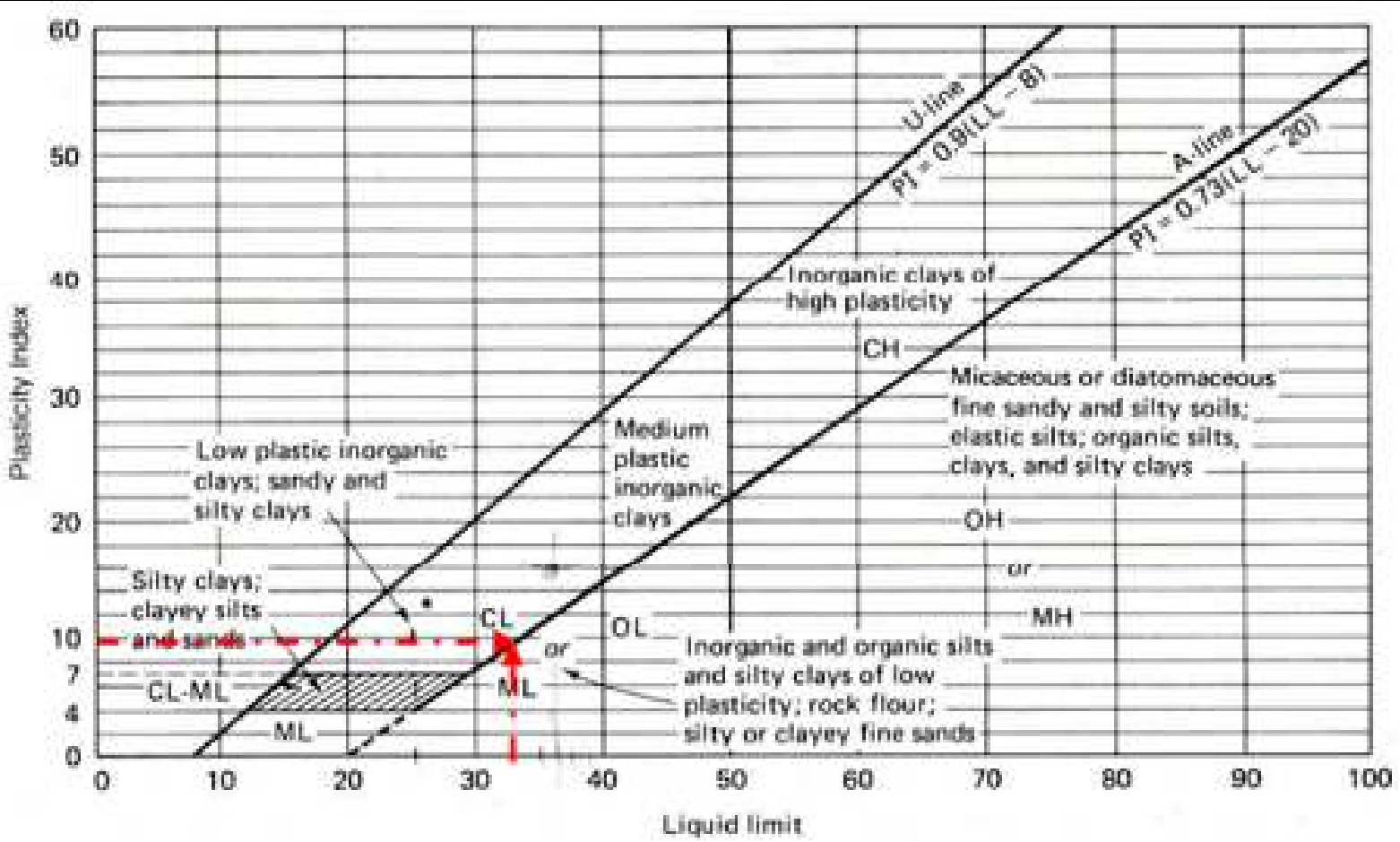

Gambar 2. Grafik plasticity chart

\section{d. Pemeriksaan Analisa Saringan dan Hidrometer}

Hasil yang diperoleh dari pemeriksaan analisa saringan adalah nilai persen lolos dari setiap saringan akan dihubungan dengan diameter saringan sehingga akan terbentuk sebuah garis yang menandakan banyaknya persen tanah berpasir yang didapatkan. Kemudian pada Analisa hidrometer didapatkan diameter butir tanah serta persentase kehalusannya. Hasil dari keduanya kemudian dihubungkan dalam titik koordinat dari setiap diameter saringan akan menghasilkan banyaknya persentase tanah yang termasuk lanau dan lempung. Hasil pemeriksaan persentase tanah yang berpasir, lanau, dan lempung dapat dilihat pada grafik berikut:

\section{Sampel 1}

Pasir $: 100 \%-85,865 \%=14,135 \%$

Lanau : $85,865 \%-14,586 \%=71,279 \%$

Lempung

$$
\text { : } 100 \%-(14,135 \%+71,279 \%)
$$

Sampel 2

$$
\begin{array}{ll}
\text { Pasir } & : 100 \%-83,438 \%=16,562 \% \\
\text { Lanau } & : 83,438 \%-11,855 \%=71,583 \% \\
\text { Lempung } & : 100 \%-(16,562 \%+71,583 \%) \\
& =11,855 \%
\end{array}
$$

Dari hasil analisis saringan dan uji hidrometer dapat disimpulkan bahwa tanah berbutir halus memiliki kandungan tanah lanau yang lebih dominan.

Menurut USCS tanah Titik 1 dan 2 termasuk berbutir halus karena persen lolos saringan 200 lebih dari $50 \%$. Nilai Indeks Plastisitas rata-rata diperoleh $9,926 \%$ yang berarti mempunyai sifat plastisitas sedang. Hubungan potensi pengembangan tanah lempung pada tiap titik dengan indeks plastisitasnya juga dapat diidentifikasi yaitu tanah mempunyai potensi pengembangan rendah karena nilai indeks plastisitas masuk pada interval $0-15 \%$ sehingga 
Paulus Civil Engineering Journal

Jurnal Teknik Sipil UKI-Paulus Makassar

https://doi.org/10.52722/pcej.v3i2.3220

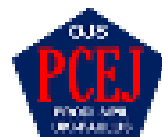

Volume 3 No.2, Juni 2021

e-ISSN 2775-4529

p-ISSN 2775-8613 dapat diketahui potensi pengembangannya. Dari grafik plasticity chart diatas tanah yang diuji ini tergolong CL atau OL (Lempung plastisitas rendah atau Lanau organik plastisitas rendah).

\section{Hasil Pengujian Pemadatan (Compaction Proctor)}

Hasil dari pemeriksaan kompaksi atau pemadatan yang telah dilakukan dapat dilihat pada tabel 6 . berikut

Tabel 6. Hasil Perhitungan Standard Proctor Titik 1

\begin{tabular}{lcccccc}
\hline & & $3 \mathrm{~kg}+730 \mathrm{ml}$ & $3 \mathrm{~kg}+780 \mathrm{ml}$ & $3 \mathrm{~kg}+830 \mathrm{ml}$ & $3 \mathrm{~kg}+880 \mathrm{ml}$ & $3 \mathrm{~kg}+930 \mathrm{ml}$ \\
\hline Berat Mold + Tanah & $\mathrm{Gr}$ & 6380 & 6430 & 6480 & 6470 & 6440 \\
Basah & $\mathrm{Gr}$ & 4900 & 4900 & 4900 & 4900 & 4900 \\
Berat Mold & $\mathrm{Gr}$ & 1480 & 1530 & 1580 & 1570 & 1540 \\
Berat Tanah Basah & $\mathrm{Cm}^{3}$ & 1337,978 & 1337,978 & 1337,978 & 1337,978 & 1337,978 \\
Volume Mold & $\mathrm{Gr} / \mathrm{Cm}^{3}$ & 1,106 & 1,144 & 1,181 & 1,173 & 1,151 \\
Kepadatan & $\mathrm{Gr} / \mathrm{Cm}^{3}$ & 0,874 & 0,893 & 0,912 & 0,895 & 0,865 \\
Kepadatan Kering & $\mathrm{Gr}$ & 5,942 & 8,354 & 8,334 & 8,179 & 8,672 \\
Berat cawan + Tanah & & & & & & \\
Basah & $\mathrm{Gr}$ & 4,893 & 6,726 & 6,647 & 6,461 & 6,752 \\
Berat cawan + Tanah & $\mathrm{Gr}$ & 0,93 & 0,93 & 0,93 & 0,94 & 0,94 \\
Kering & $\mathrm{Gr}$ & 5,012 & 7,428 & 8,311 & 7,239 & 7,731 \\
Berat cawan & $\mathrm{Gr}$ & 3,963 & 5,799 & 6,738 & 5,521 & 5,811 \\
Berat Tanah Basah & $\mathrm{Gr}$ & 1,050 & 1,629 & 1,573 & 1,718 & 1,920 \\
Berat Tanah Kering & $\%$ & 26,597 & 28,081 & 29,510 & 31,097 & 33,030 \\
Berat Air & & 1,530 & 1,496 & 1,465 & 1,431 & 1,393 \\
Kadar air & & & & & & \\
ZAV = Gs/(1+W/100*Gs) & & & &
\end{tabular}

Kepadatan Kering Vs Kadar Air

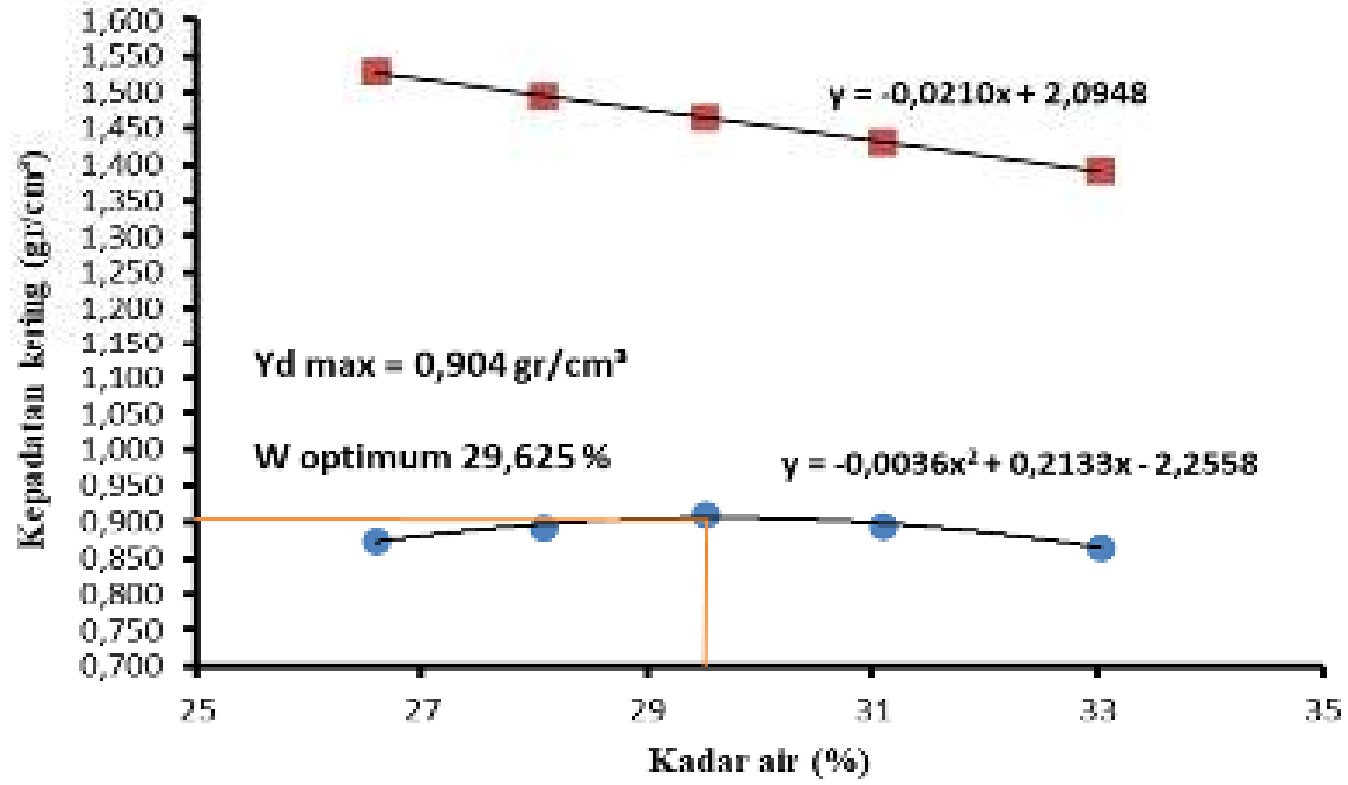

Gambar 3. Kepadatan Kering ( $\left.\gamma_{d r y}\right)$ vs Kadar Air $(\omega)$ Titik 2 
Paulus Civil Engineering Journal

Jurnal Teknik Sipil UKI-Paulus Makassar

https://doi.org/10.52722/pcej.v3i2.3220

Dari Gambar 3, pada grafik di peroleh persamaan ZAV $=-0,0210 \omega+2,0948$ dan $\gamma_{d r y}=-0,0036 \omega^{2}+$ $0,2133 \omega-2,2558$, nilai kadar air optimum serta kepadatan kering diperoleh dari persamaan parabola $\gamma_{\text {dry }}$.

Secara grafis dapat diplot garis lurus secara vertikal dan horizontal yang menyentuh titik puncak dari parabola tersebut, sehingga menghasilkan nilai untuk kadar air optimum sebesar 29,625 \% dan kepadatan kering $0,904 \mathrm{gr} / \mathrm{cm}^{3}$. Sedangkan secara analisis, nilai untuk kadar air optimum dan kepadatan kering diperoleh dari persamaan linear yang dihasilkan grafik di atas, yaitu:

Untuk hubungan antara kadar air $(\omega)$ dengan ZAV (Zero Air Void), diperoleh persamaan:

$$
\begin{aligned}
& Z A V=-0,0210 \omega+2,0948 \\
& Z A V=-0,0210 \omega+2,0948 ; \\
& \text { Saat } Z A V=0, \text { maka: } \\
& 0=-0,0210 \omega+2,0948 \\
& 0,0210 \omega=2,0948 \\
& \omega=2,0948 / 0,0210 \\
& \omega=99,752 \%
\end{aligned}
$$

Sedangkan maksud dari ZAV $100 \%$ menunjukkan bahwa kondisi pori-pori tanah sudah tidak
Volume 3 No.2, Juni 2021

e-ISSN 2775-4529

p-ISSN 2775-8613

mengandung udara lagi. Didapatkan hasil dari persamaan di atas yaitu $\omega=99,752 \%$ atau dapat dianggap $100 \%$ udara di dalam pori sudah tidak ada lagi.

Untuk hubungan antara Kepadatan Kering $\left(\gamma_{d r y}\right)$ dan Kadar Air ( $\omega)$, diperoleh persamaan :

$$
\gamma_{d r y}=-0,0036 \omega^{2}+0,2133 \omega-2,2558 .
$$

Bila diselesaikan :

\begin{tabular}{|c|c|c|c|c|c|c|}
\hline & & $3 \mathrm{~kg}+750 \mathrm{ml}$ & $3 \mathrm{~kg}+800 \mathrm{ml}$ & $3 \mathrm{~kg}+850 \mathrm{ml}$ & $3 \mathrm{~kg}+900 \mathrm{ml}$ & $3 \mathrm{~kg}+950 \mathrm{~m}$ \\
\hline $\begin{array}{l}\text { Berat Mold + Tanah } \\
\text { Basah }\end{array}$ & $\mathrm{Gr}$ & 6440 & 6490 & 6530 & 6520 & 6500 \\
\hline Berat Mold & $\mathrm{Gr}$ & 4900 & 4900 & 4900 & 4900 & 4900 \\
\hline Berat Tanah Basah & $\mathrm{Gr}$ & 1540 & 1590 & 1630 & 1620 & 1600 \\
\hline Kepadatan & $\mathrm{Gr} / \mathrm{Cm}^{3}$ & 1,151 & 1,188 & 1,218 & 1,211 & 1,196 \\
\hline Kepadatan Kering & $\mathrm{Gr} / \mathrm{Cm}^{3}$ & 0,896 & 0,917 & 0,929 & 0,916 & 0,899 \\
\hline $\begin{array}{l}\text { Berat cawan + Tanah } \\
\text { Basah }\end{array}$ & $\mathrm{Gr}$ & 8,956 & 9,524 & 8,823 & 8,872 & 9,007 \\
\hline $\begin{array}{l}\text { Berat cawan + Tanah } \\
\text { Kering }\end{array}$ & $\mathrm{Gr}$ & 7,175 & 7,567 & 6,952 & 6,941 & 6,999 \\
\hline Berat cawan & $\mathrm{Gr}$ & 0,93 & 0,94 & 0,93 & 0,94 & 0,92 \\
\hline Berat Tanah Basah & $\mathrm{Gr}$ & 8,029 & 8,587 & 7,893 & 7,937 & 8,084 \\
\hline Berat Tanah Kering & $\mathrm{Gr}$ & 6,248 & 6,629 & 6,022 & 6,006 & 6,077 \\
\hline Berat Air & $\mathrm{Gr}$ & 1,781 & 1,958 & 1,871 & 1,931 & 2,008 \\
\hline Kadar air & $\%$ & 28,505 & 29,551 & 31,085 & 32,175 & 33,083 \\
\hline$Z A V=G s /\left(1+W / 100^{*} G s\right)$ & & 1,490 & 1,467 & 1,435 & 1,413 & 1,395 \\
\hline
\end{tabular}

$$
\gamma_{d r y}=-0,0036 \omega^{2}+0,2133 \omega-2,2558
$$

Turunan pertama dari pers. $\gamma_{\text {dry }}$ merupakan garis singgung $\frac{\partial \gamma_{d r y}}{\partial \omega}=-0,0072 \omega+0,2133$

$$
\begin{aligned}
& \omega_{\mathrm{opt}} \text { diperoleh saat } \frac{\partial \gamma_{d r y}}{\partial \omega}=0 \\
& \frac{\partial \gamma_{d r y}}{\partial \omega}=0, \text { maka } 0,0072 \omega_{\text {opt }}=0,2133 \\
& \omega_{\text {opt }}=0,2133 / 0,0072 \\
& \omega_{\mathrm{opt}}=29,625 \%
\end{aligned}
$$

$\gamma_{d r y}$ pada kondisi $\omega_{\mathrm{opt}}$ sebagai berikut:

$$
\begin{aligned}
\gamma_{d r y}= & -0,0036 \omega^{2}+0,2133 \omega-2,2558 \\
\gamma_{d r y}= & \left(-0,0036\left(29,625^{2}\right)\right)+(0,2133(29,625)) \\
& -2,2558 \\
\gamma_{d r y}= & (-3,160)+6,319-2,2558 \\
\gamma_{d r y}= & 0,904 \mathrm{gr} / \mathrm{cm}^{3}
\end{aligned}
$$

Tabel 7. Hasil perhitungan Standard Proctor titik 2 


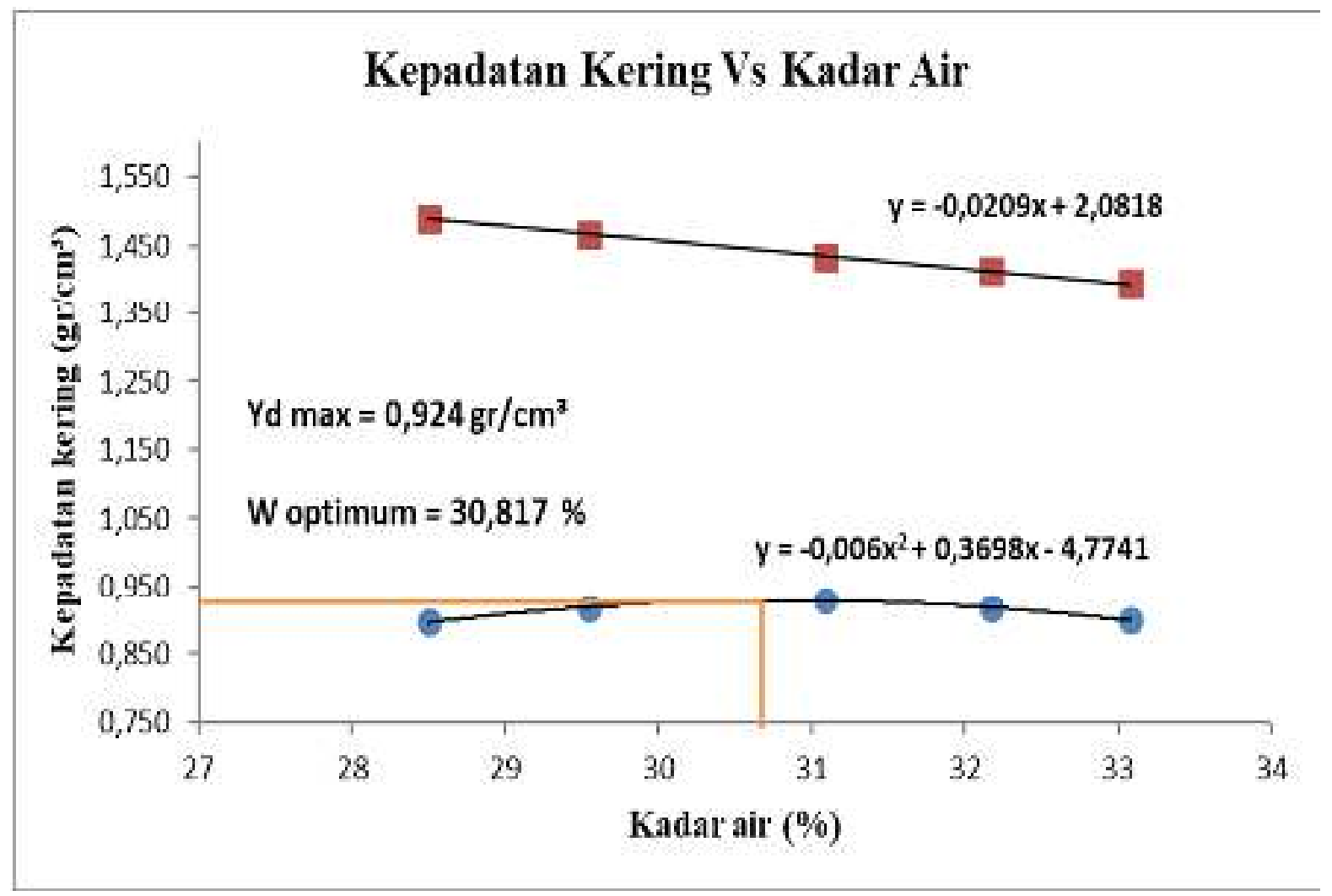

Gambar 4. Kepadatan Kering $\left(\gamma_{d r y}\right)$ vs Kadar Air $(\omega)$ Titik 2

Dari Gambar 4, pada grafik di peroleh persamaan ZAV $=-0,0209 \omega+2,0818$ dan $\gamma_{d r y}=-0,0006 \omega^{2}+$ $0,3698 \omega-4,7741$, nilai kadar air optimum serta kepadatan kering diperoleh dari persamaan parabola $\gamma d r y$.

Secara grafis dapat diplot garis lurus secara vertikal dan horizontal yang menyentuh titik puncak dari parabola tersebut, sehingga menghasilkan nilai untuk kadar air optimum sebesar 30,817 \% dan kepadatan kering $0,924 \mathrm{gr} / \mathrm{cm}^{3}$. Sedangkan secara analisis, nilai untuk kadar air optimum dan kepadatan kering diperoleh dari persamaan linear yang dihasilkan grafik di atas, yaitu:

Untuk hubungan antara kadar air $(\omega)$ dengan ZAV (Zero Air Void), diperoleh persamaan :

$$
\begin{aligned}
& Z A V=-0,0209 \omega+2,0818 \\
& Z A V=-0,0209 \omega+2,0818 \\
& \text { Saat } Z A V=0, \text { maka }: \\
& 0=-0,0209 \omega+2,0818 \\
& 0,0209 \omega=2,0818 \\
& \omega=2,0818 / 0,0209 \\
& \omega=99,608 \%
\end{aligned}
$$

bahwa kondisi pori-pori tanah sudah tidak mengandung udara lagi. Diperoleh hasil dari persamaan di atas adalah $\omega=99,608 \%$ atau dapat dianggap $100 \%$ udara dalam pori sudah tidak ada lagi

Untuk hubungan antara Kepadatan Kering $\left(\gamma_{\text {dry }}\right)$ dan Kadar Air $(\omega)$, diperoleh persamaan:

$$
\gamma_{d r y}=-0,0006 \omega^{2}+0,3698 \omega-4,7741
$$

Bila diselesaikan :

$$
\gamma_{d r y}=-0,0006 \omega^{2}+0,3698 \omega-4,7741
$$

Turunan pertama dari pers. $\gamma_{\text {dry }}$ merupakan garis singgung

$$
\begin{aligned}
& \frac{\partial \gamma_{d r y}}{\partial \omega}=-0,0012 \omega+0,3698 \\
& \omega_{\text {opt }} \text { diperoleh saat } \frac{\partial \gamma_{d r y}}{\partial \omega}=0 \\
& \frac{\partial \gamma_{d r y}}{\partial \omega}=0, \text { maka } 0,0012 \omega_{\text {opt }}=0,3698 \\
& \omega_{\text {opt }}=0,3698 / 0,0012 \\
& \omega_{\text {opt }}=30,81
\end{aligned}
$$

$\gamma_{\text {dry }}$ pada kondisi $\omega_{\text {opt }}$ sebagai berikut:

$$
\gamma_{d r y}=-0,0006 \omega^{2}+0,3698 \omega-4,7741
$$

Sedangkan maksud dari ZAV 100\% menunjukkan 


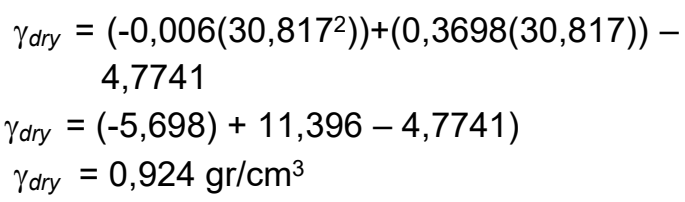

Hasil dari pengujian pemadatan atau kompaksi Proctor dengan penambahan abu arang tempurung kelapa dapat dilihat pada tabel 8 . berikut :

3. Pengujian Kompaksi dengan Penambahan Abu Arang Tempurung Kelapa

Tabel 8. Hasil Pengujian Kompaksi Proctor

\begin{tabular}{cccc}
\hline Abu Arang Tempurung & \multicolumn{3}{c}{ Kepadatan Kering $\left(\gamma_{\text {dry }}\right)\left(\mathrm{gr} / \mathrm{cm}^{3}\right)$} \\
\cline { 2 - 4 } Kelapa & Sampel 1 & Sampel 2 & Rata-rata \\
\hline $0 \%$ & 0,842 & 0,881 & 0,862 \\
$4 \%$ & 0,867 & 0,905 & 0,886 \\
$6 \%$ & 0,904 & 0,924 & 0,914 \\
$8 \%$ & 0,934 & 0,951 & 0,943 \\
$10 \%$ & 0,959 & 0,965 & 0,962 \\
\hline
\end{tabular}

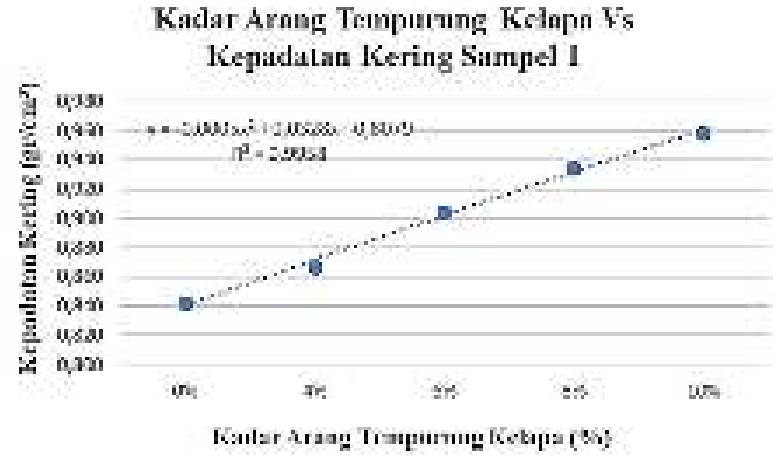

Gambar 5. Kadar Abu Arang Tempurung Kelapa vs Kepadatan Kering $\left(\gamma_{\text {dry }}\right)$ Titik 1

Pencampuran tanah dengan abu arang tempurung kelapa pada Titik 1 menunjukkan nilai kepadatan kering terjadi peningkatan dengan penambahan persen abu arang tempurung kelapa dari $0 \%$ sebesar $0,842 \mathrm{gr} / \mathrm{cm}^{3}$ sampai $10 \%$ sebesar 0,959

$\mathrm{gr} / \mathrm{cm}^{3}$, Hal ini berarti sampel tanah pada Titik 1 mengalami peningkatan sebesar $13,895 \%$.

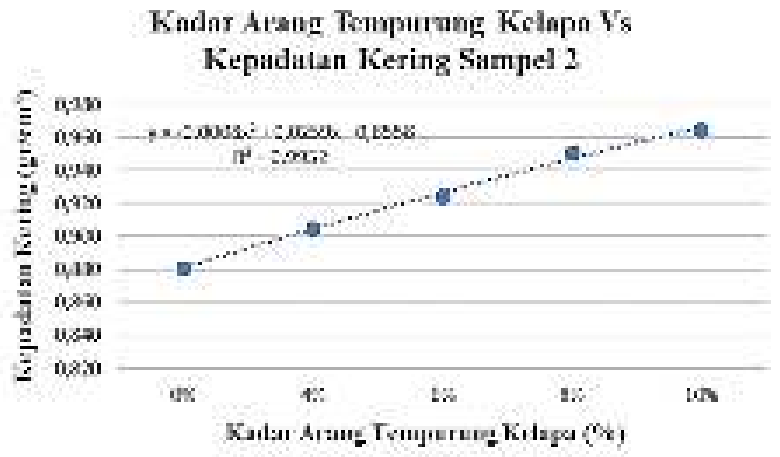

Gambar 6. Kadar Abu Arang Tempurung Kelapa vs Kepadatan Kering $\left(\gamma_{\text {dry }}\right)$ Titik 2

Pencampuran tanah dengan abu arang tempurung kelapa pada Titik 2 menunjukkan nilai kepadatan kering terjadi peningkatan dengan penambahan persen abu arang tempurung kelapa dari $0 \%$ sebesar $0,881 \mathrm{gr} / \mathrm{cm}^{3}$ sampai $10 \%$ sebesar 0,965 $\mathrm{gr} / \mathrm{cm}^{3}$, hal ini berarti sampel tanah pada Titik 2 mengalami peningkatan sebesar $9,534 \%$.

Dengan mengambil nilai rata-rata pada pencampuran tanah dengan abu arang tempurung kelapa menunjukkan nilai kepadatan kering $\left(\gamma_{\text {ary }}\right)$ terjadi peningkatan dengan penambahan $\%$ abu arang tempurung kelapa dari $0 \%$ sebesar 0,862 $\mathrm{gr} / \mathrm{cm}^{3}$ sampai $10 \%$ sebesar $0,962 \mathrm{gr} / \mathrm{cm}^{3}$, Hal ini berarti sampel tanah mengalami peningkatan sebesar $11,60 \%$.

Berdasarkan hal tersebut di atas menunjukkan bahwa dengan kadar air yang optimum dan penambahan abu arang tempurung kelapa hingga $10 \%$ masih menunjukkan terjadi peningkatan terhadap kepadatan kering.

\section{KESIMPULAN}

Sampel tanah dari Jalan Damai Kecamatan Tanralili Kabupaten Maros merupakan tanah lempung organik karena mendapatkan hasil nilai berat jenis $2,58 \mathrm{gr} / \mathrm{cm}^{3}$ dengan kadar air tanah asli sebesar 28,811\%, serta nilai Indeks Plastisitas $9,926 \%$ dengan sifat plastisitas tergolong sedang dari interval $7 \%-17 \%$. Sedangkan menurut metode USCS, tanah tersebut tergolong OL (Lanau organik plastisitas rendah) dan dengan metode AASTHO, 
sampel tanah tergolong A-4 dengan jenis material pokok tanah lanau dan tingkat kegunaan sebagai subgrade cukup baik hingga buruk

Dari hasil pengujian Pemadatan Tanah (Standard Proctor) dengan penambahan abu arang tempurung kelapa memberikan pengaruh peningkatan terhadap kepadatan kering $\left(\gamma_{d r y}\right)$. Nilai kepadatan kering meningkat dari penambahan $4 \%$ sampai penambahan $10 \%$, hal ini juga tidak menutupi kemungkinan akan terus meningkat pada kadar abu arang tempurung elapa yang lebih besar lagi.

\section{DAFTAR PUSTAKA}

[1] B. M. Das, 1995. Mekanika Tanah (Prinsipprinsip Rekayasa Geoteknis), Jakarta: Erlangga.

[2] D. Soedarmo and E. Purnomo, 1993. Mekanika Tanah 1, Malang: Kanisius.

[3] Departemen Pekerjaan Umum, 2006. Pekerjaan Tanah, Jakarta: Direktorat Jenderal Bina Marga.

[4] D. Panguriseng, 2001. Stabilisasi Tanah, Makassar: Universitas 45 Makassar.

[5] R. K. Rustam, 2019. "Pengaruh Penambahan Abu Arang Tempurung Kelapa Terhadap Kuat Geser Tanah Lempung Di Daerah Makarti Jaya," Jurnal Deformasi, Volume. 4, Nomor. 2. HIm. 82-91.
[6] Departemen Pekerjaan Umum, 2006. Pedoman Pekerjaan Tanah Dasar Untuk Pekerjaan Jalan, Jakarta: Direktorat Jenderal Bina Marga.

[7] B. Santoso, H. Suprapto dan S. H. S., 1998. Dasar Mekanika Tanah, Depok: Gunadarma.

[8] G. S. Budi, 2011. Pengujian Tanah di Laboratorium, Yogyakarta: Graha IImu.

[9] A. J. Karaseran, 2015. "Pengaruh Bahan Campuran Arang Tempurung Terhadap Konsolidasi Sekunder Pada Lempung Ekspansif," Jurnal Sipil Statik, Volume. 3, Nomor. 8. HIm. 543-553.

[10] G. K. Bumbungan, 2019. Pengaruh Penambahan Abu Batubara terhadap Hasil Uji Kompaksi, Makassar: Skripsi. Universitas Kristen Indonesia Paulus.

[11] D. M. Pangadongan, R. Rachman, dan I. L. K. Wong, 2020, "Pengaruh Penambahan Bubuk Gypsum Pada Tanah Lempung Terhadap Uji California Bearing Ratio (CBR)," Paulus Civil Engineering Journal, vol. 2, no. 4, hlm. 263272. 